\title{
Impact of fossil fuels, renewable energy consumption and industrial growth on carbon emissions in Latin American and Caribbean economies
}

\author{
Muhammad Khalid ANSER ${ }^{1}$, Imran HANIF $^{2 *}$, Majed ALHARTHI ${ }^{3}$ and Imran Sharif CHAUDHRY ${ }^{4}$ \\ ${ }^{1}$ School of Public Administration, Xi'an University of Architecture and Technology, China. \\ ${ }^{2}$ Department of Economics, University of Management and Technology, C-II Johar Town Lahore, Pakistan. \\ ${ }^{3}$ Finance Department College of Business, King Abdulaziz University, Rabigh, Saudi Arabia. \\ ${ }^{4}$ School of Economics, Bahauddin Zakariya University Multan, Pakistan. \\ *Corresponding author; email: imranhanif@umt.edu.pk
}

Received: June 22, 2019; accepted: December 24, 2019

\begin{abstract}
RESUMEN
Se examina el impacto del consumo de combustibles fósiles, el uso de energías renovables y el desarrollo industrial en las emisiones de carbono en las economías emergentes de América Latina y el Caribe. Se desarrolla un índice de desarrollo industrial usando indicadores industriales competitivos, y se utiliza un método de los momentos generalizado de dos pasos como estimador robusto, el cual implica un panel de 16 economías de bajos y medianos ingresos para el periodo 1990-2015. Los resultados empíricos muestran una relación en forma de $\mathrm{U}$ invertida entre el crecimiento económico y las emisiones de carbono, y confirman la existencia de una curva ambiental de Kuznets para la región. Los resultados indican que el crecimiento industrial y el consumo de combustibles fósiles contribuyen de manera significativa a las emisiones de carbón en la región; asimismo, destacan que, con base en la competitividad en la manufactura y la transición de tecnologías simples a sofisticadas, el desarrollo industrial basado en tecnología avanzada produce bienes de manera competitiva con menores emisiones de carbono. Los hallazgos sugieren que este tipo de desarrollo industrial avanzado es imprescindible para alcanzar un desarrollo económico sostenible. De esta manera, el avance tecnológico y el consumo de energías renovables tienen el potencial tanto de satisfacer la creciente demanda de productos y energía, como de controlar las emisiones de carbono en los países en desarrollo de América Latina y el Caribe.
\end{abstract}

\begin{abstract}
This study examines the impact of fossil fuels consumption, renewable energy use and industrial growth on carbon emissions in the developing economies of Latin America and the Caribbean. An industrial growth index is developed using competitive industrial indicators, and a two-step system generalized method of moments robust estimator is employed, involving a panel of 16 middle- and lower-middle-income economies for the period 1990 to 2015. The empirical results show an Inverted-U shaped relationship between economic growth and carbon emissions and confirm the existence of the environmental Kuznets curve for the region. The results indicate that industrial growth and consumption of fossil fuels are significantly contributing to carbon emissions in the region. The results highlight that, based on competitiveness in manufacturing and the transition from simple to sophisticated technologies, advance technology-based industrial growth increases the potential to produce goods competitively with lower carbon emissions. The findings suggest that such advanced industrial growth is unavoidable to attain sustainable economic growth. Thus, technological advancement and consumption of renewable energies have the potential to both meet the rising demand for goods and energy and to control carbon emissions in the developing countries of Latin America and the Caribbean.
\end{abstract}

Keywords: Carbon emissions, fossil fuels, economic growth, industrial growth, renewable energy. 


\section{Introduction}

The consumption of energy is a standard for gauging the pace of economic progress and industrial promotion. Energy use also acts as a catalyst toward swift economic growth in both developed and developing countries. Generally speaking, the consumption of non-renewable energy in developing economies accelerates the pace of economic growth, but it also massively contributes to toxic gas emissions and increased environmental challenges (Hanif and Gago-de-Santos, 2017; Hanif, 2017). For instance, in 2013, global emissions of $\mathrm{CO}_{2}$ from non-renewable energy sources (including the fossil fuels mixes) reached approximately $36.2 \mathrm{Gt}$ of $\mathrm{CO}_{2}$ equivalent. Of the total increase in carbon emissions, approximately $43 \%$ derived from coal mix, 33\% from oil mix, and 24\% from gas mix (Hanif, 2017). Clearly, carbon emissions and environmental degradation are two key emerging global challenges faced by both developed and developing countries in the 21 st century (Pablo-Remero and de-Jesús, 2016). Moreover, the higher reliance on fossil fuels mixes to promote industrial growth (and to increase value-added manufacturing) in developing countries make them especially prone to environmental issues (Wolde-Rufael, 2010). In association with climate change, the position of regions like Latin America and the Caribbean proves highly asymmetrical and unbalanced; although this region has played a minor role in current environmental degradation, it is susceptible to environmental impacts to a greater degree (Hanif, 2017; ECLAC, 2015). This research therefore focuses primarily on the developing economies of Latin America and the Caribbean.

As with other developing nations, the economies of Latin America and the Caribbean are struggling to promote economic growth and to improve their production of goods; this drives rising energy consumption and consequent harmful impacts, notably air pollution and land degradation (Pao and Tsai, 2011; Robalino-López et al., 2014). In world development rankings, industrialized countries rank in the group of 'developed' nations, moving 'developing' economies to follow suit and promote industrialization and production. However, the industrial sectors in developing countries usually pursue highly polluting activities in order to produce goods. On the one hand, they make these efforts to produce more goods and to improve value-added manufacturing; on the other, developing countries tend to use readily available fossil fuels mixes to keep the costs of production low. Greater consumption of fossil fuels exerts greater pressures on the environment and natural resources as through deforestation, desertification, and the erosion of topsoil (Orubu and Omotor, 2011).

To develop an impartial nexus of industrial growth with carbon emissions, there is a need to construct a robust variable for industrial growth in lieu of proxies, which are usually biased. Specifically, the indicators used to gauge industrial growth are rooted in subjectivity and usually calculated through a small component. Therefore, they are ill-equipped to measure the pace of industrial growth over time. This study contributes to the existing literature by providing an answer to this problem, by developing an Industrial Development point Panel (IDPP) based on the competitive industrial performance index. Industrial competitiveness can be described as the capacity of countries to increase their presence in domestic and international markets while promoting industrial sectors and activities with higher value added and technological levels. As defined, the competitive industrial performance index can be developed through competitive industrial performance indicators such as per capita manufacturing exports, per capita manufacturing value added, industrial intensity, and export quality (for a graphical presentation see Figs. SM1-SM4 in the supplementary material). Furthermore, energy variables bifurcated on the basis of fossil fuels and renewables (i.e., wind, hydropower, solar energy) are employed to measure non-renewable and renewable energy consumption, respectively.

In the relevant literature, traditional regression approaches are used to determine the impact of industrial growth and energy consumption on carbon emissions (Peng and Bao, 2006). Unfortunately, the traditional approaches scarcely address the complexity of relationships inherent in industrial growth and energy consumption vis-à-vis carbon emissions. Furthermore, such regression models do not identify well the exogenous and endogenous regressors used to develop such a nexus. Therefore, to offer both robust results and an effective policy framework for coping with growing environmental challenges, the present research employs an econometric strategy to account 
for the simultaneity bias, omitted variable bias, and estimation errors in the variables (Arellano and Bond, 1998). To mitigate these issues and report the most reliable results, a two-step system generalized method of moment (GMM) with moving averages is applied (Blundell and Bond, 1998). Also, as the data series considered in this research are cross-country, a robust version of a two-step system GMM is applied to control for heterogeneity in the data series (Bond et al., 2001).

The emphasis of this research is put on answering the following questions in relation with developing economies: (1) Does competitive industrial growth contribute to carbon emissions?, and (2) how much do fossil fuels mixes and renewable energies respectively contribute to carbon emissions? We also seek to mitigate endogeneity and heterogeneity in order to control the robustness of results, and so we have instrumented the variables and employed over-identification restrictions and various tests to check their quality and validity. We find that the empirical results reported in this paper are reliable, the quality of results having been further tested by applying various diagnostic tests. The empirical results of this study reveal the influence of industrial growth and energy consumption on carbon emissions in Latin America and the Caribbean with the help of the latest data of Argentina, Bolivia, Brazil, Colombia, Costa Rica, Guatemala, Honduras, Jamaica, Saint Lucia, Mexico, Panama, Peru, Paraguay, El Salvador, Suriname, and Venezuela for the period 1990-2015. The findings of this study may prove beneficial as an essential reference for policymakers seeking to advance impartial sustainable development by controlling the effects of industrial growth and energy consumption on carbon emissions.

The rest of the study is structured as follows. Section two explains the data sources and describes the variables and methodology. Empirical testing is performed in section three. Interpretation and discussion of results are given in section four, and conclusions are drawn in section five.

\section{Data and methodology}

For empirical analysis, a panel data of 16 developing countries from the period 1990-2015 is used, collected from the World Development Indicators (WDI) of the World Bank, annual reports of the International Energy Agency (IEA), and a database of the United Nations Statistical Division. Due to limitations on data availability, we have eliminated certain developing countries of the region and selected only 16 . The study has employed carbon emissions, described below, as a dependent variable; those that follow carbon emissions are independent variables.

Carbon emissions (CEM) are calculated and estimated as annual per capita emissions in metric tons. A similar measure is used by Kais and Sami (2016) and Kasman and Duman (2015).

Competitive industrial growth (CIG) is an annual country score assigned in the Industrial Development Point Panel, based on the fiscal year 2010. The study's hypothesis is that improvement in CIG has a negative association with carbon emissions.

Annual per capita fossil fuels consumption in metric tons of oil equivalent (FFE) is used to examine the impact of oil, coal, and gas consumption on carbon emissions in the atmosphere following the work of Hanif and Gago-de-Santos (2017). The hypothesis is that the consumption of fossil fuels has a positive impact on carbon emissions.

Renewable energy consumption (REC) is the per capita consumption of renewable energy calculated by the consumption of power in kilowatts per hour. It is similar to the measure used in the studies of Hanif $(2017,2018 \mathrm{a})$. This study's hypothesis is that the consumption of renewable energy has a negative impact on carbon emissions.

Economic growth (GDP) is used to measure the rate of growth in an economy. Annual per capita real gross domestic product (GDP) is estimated based on the fiscal year 2010 in US dollars. A similar measure has been used in the studies of Kais and Sami (2016), Hanif (2017), and Hanif and Gago-de-Santos (2017). This study's hypothesis is that economic growth and carbon emissions have a positive relationship within the context of the sampled developing countries.

Square of economic growth $\left(\mathrm{GDP}^{2}\right)$ is a $\log$ of the square of the economic growth rate. The use of $\mathrm{GDP}^{2}$ is in line with the theory of the Environmental Kuznets Curve (EKC). In order to avoid possible multicollinearity in the estimated model, 
we transformed the square of the real per capita gross domestic product by taking the log of the series (Orubu and Omotor, 2011; Hanif, 2018; Pablo-Romero and de Jesús, 2016). The study's hypothesis is that the square of per capita economic growth has a negative impact on carbon emissions.

Urbanization (URB) is used to estimate the pace of urbanization (here taken as population accumulation in urban areas above the level of 1 million). A similar measure has been used in the studies of Rafiq et al. (2016) and Hanif (2017). This study's hypothesis is that urbanization growth has a positive association with carbon emissions.

To develop an econometric model, the extended form of the Environmental Kuznets Curve theory is employed here. A similar model has been used in prior studies such as Tamaziane et al. (2009), Fodha and Zaghdoud (2010), Hanif (2017, 2018a), and Hanif and Gago-de-Santos (2017). The generalized functional form of the extended model can be written as follows:

$C E M_{i t}=f\left(G D P_{i t}, G D P^{2}{ }_{i t}, C I G_{i t}, \theta_{i t}\right)$

An econometric model based on the EKC is as follows:

$C E M_{i t}=a_{0}+a_{1} G D P_{i t}+$

$a_{2} G D P^{2}{ }_{i t}+a_{3} C I G_{i t}+a_{n} \theta_{i t}+\mu_{i t}$ where is the group of additional variables of interest in the country $i$ and time $t$; is the slope of $n$ control variables, and is an error term. The extended form of the model can be written as:

$$
\begin{aligned}
& C E M_{i t}=a_{0}+a_{1} G D P^{i t}+a_{2} G D P^{2}+ \\
& a_{3} C I G_{i t}+a_{4} F F E_{i t}+a_{5} R E C_{i t}+a_{6} U R B_{i t}+\mu_{i t}
\end{aligned}
$$

\section{Empirical results estimation}

In the observed sample, the highest competitive industrial growth observed was in Saint Lucia in the fiscal years 1998-1999, 2003-2004, and 2013-2014. Panama in 2008-2009 and Suriname in 2000-2001 ranked at the second position in the observed panel. The lowest competitive industrial growth was observed in Mexico in the fiscal year 2000-2001. The highest growth in real per capita GDP was observed in Venezuela in the fiscal year 2008-2009, and the lowest level of per capita GDP was observed in Bolivia in the fiscal year 1990-1991. The highest emissions of $\mathrm{CO}_{2}$ were observed in Venezuela in 2001-2002, while the lowest emissions were observed in El Salvador during the fiscal year 1990-1991. The summary statistics of the dependent and independent variables are given in Table I.

To investigate the incidence of multicollinearity, the findings of the correlation matrix are presented in Table II. These findings reveal that CEM are weakly associated with GDP, GDP ${ }^{2}$, CIG, FFE, REC, and URB. Thus, the results of correlation matrix depict that the proposed model does not suffer from multicollinearity.

Table I. Summary statistics.

\begin{tabular}{lcrrrr}
\hline Variables & Observations & \multicolumn{1}{c}{ Mean } & $\begin{array}{c}\text { Standard } \\
\text { deviation }\end{array}$ & Minimum & Maximum \\
\hline CEM & 395 & 2.15 & 1.49 & 0.47 & 7.61 \\
GDP & 400 & 5315.92 & 3060.91 & 1068.31 & 14687.98 \\
GDP $^{2}$ & 400 & 28259005.4 & 9369170.03 & 1141286.26 & 215736756 \\
CIG & 400 & 76.42 & 30.98 & 19.01 & 137.00 \\
FFE & 392 & 61.71 & 24.36 & 09.26 & 90.65 \\
REC & 389 & 33.44 & 19.26 & 2.31 & 74.96 \\
URB & 400 & 29.97 & 9.39 & 11.66 & 48.14 \\
\hline
\end{tabular}

CEM: carbon emissions; GDP: gross domestic product (economic growth); GDP²: square of economic growth; CIG: competitive industrial growth; FFE: annual per capita fossil fuels consumption in metric tons of oil equivalent; REC: renewable energy consumption; URB: urbanization.

Source: author's calculation. 
Table II. Correlation matrix.

\begin{tabular}{lrllllll}
\hline Variables & CEM & GDP & GDP $^{2}$ & CIG & FFE & REC & URB \\
\hline CEM & 1.00 & & & & & & \\
GDP & 0.24 & 1.00 & & & & & \\
GDP $^{2}$ & -0.07 & 0.36 & 1.00 & & & & \\
CIG & 0.05 & 0.01 & 0.21 & 1.00 & & & \\
FFE & 0.17 & 0.09 & 0.35 & 0.12 & 1.00 & & \\
REC & -0.19 & 0.06 & 0.08 & 0.16 & -0.28 & 1.00 & \\
URB & 0.20 & 0.29 & 0.19 & 0.14 & 0.31 & 0.41 & 1.00 \\
\hline
\end{tabular}

CEM: carbon emissions; GDP: gross domestic product (economic growth); $\mathrm{GDP}^{2}$ : square of economic growth; CIG: competitive industrial growth; FFE: annual per capita fossil fuels consumption in metric tons of oil equivalent; REC: renewable energy consumption; URB: urbanization.

Source: author's calculation.

In a next step, we examined stationarity in the data series, which is mandatory for the calculation of reliable results. The presence of unit root in a data series produces unreliable and spurious regression results. Therefore, to diagnose the presence of unit root, and due to unbalanced panel data, we used the highly recommended Fisher-type unit root test, whose findings appear in Table III.

The findings of the unit root test show that the developed null hypothesis is rejected, while the alternative hypothesis is accepted, which in turn verifies that all the data series are stationary at level. Before conducting the pragmatic and practical examination, we verified the homoscedasticity and endogeneity in the model. The findings of a Breusch-Pagan test
(Breusch and Pagan, 1979) for homoscedasticity are given as follows:

$$
\text { Chi2(6) }=434.82 ; \quad \text {-value }>\text { Chi2 }=0.00
$$

The results of the Breusch-Pagan test reject the null hypothesis of constant variance in Eq. (3). The estimated lower p-value supports the acceptance of the alternative hypothesis and rejection of the null hypothesis (i.e., stable and consistent variance of the parameters). Thus, the data series in our model is suffering from heteroscedasticity.

To test the endogeneity of the model, a DurbinWu-Hausman test for endogeneity was, with the following results:

Table III. Results based on Fisher-type unit root tests.

Ho: All panels contain unit roots

\begin{tabular}{llllllllr}
\hline $\begin{array}{l}\text { AR parameter: panel-specific } \\
\text { Panel means: included }\end{array}$ & & \multicolumn{7}{c}{$\begin{array}{c}\text { Number of panels }=16 \\
\text { Average number of periods =24.78 }\end{array}$} \\
\hline & & CEM & GDP & GDP & CIG & FFE & REC & URB \\
\hline Inverse chi-squared & P & 94.83 & 90.35 & 89.53 & 53.21 & 110.74 & 90.21 & 104.27 \\
Inverse normal & Z & -5.63 & -5.05 & -4.97 & -6.21 & -6.89 & -5.01 & -5.94 \\
Inverse logit t & L* & -7.48 & -6.35 & -5.71 & -7.08 & -7.13 & -6.17 & -8.91 \\
Modified inversed chi-squared & Pm & 18.65 & 14.79 & 11.56 & 17.42 & 21.35 & 14.98 & 23.94 \\
\hline
\end{tabular}

Ho: null hypothesis; AR: autorregresive; CEM: carbon emissions; GDP: gross domestic product (economic growth); GDP²: square of economic growth; CIG: competitive industrial growth; FFE: annual per capita fossil fuels consumption in metric tons of oil equivalent; REC: renewable energy consumption; URB: urbanization.

Source: author's calculation. 
Durbin (score) Chi2(6) $=62.89 ;$ p-value $=0.00$

Wu-Hausman $F(6,389)=138.07 ; p-$ value $=0.00$

Here, the lower p-value indicates the acceptance of the alternative hypothesis and rejection of the null hypothesis, which confirms endogeneity in the variables. Therefore, to cope with endogeneity and heteroscedasticity, the study pursued a robust version of a two-step system-GMM estimator with moving averages. It is worth mentioning that, to deal with endogeneity in the variables, Arellano and Bond (1988) recommend the difference-GMM using first-difference lagged variables as an instrument for the identical moment conditions. However, first-difference lagged variables lead to severe deviation bias in the case of limited samples, and thus prove to be weak instruments. For this reason, Blundell and Bond (1998) recommend a most-flexible system-GMM in which instruments are developed by using the differences and level information. In addition, system-GMM develops a double equation system by introducing a level equation and a first difference equation. Introduction of the level equation into system-GMM turns the lagged variables of the level equation into instruments, thereby increasing the number of instruments. As a result, system-GMM provides more information on the sample, as compared to difference-GMM. With a reasonable sample size (such as for a smaller $n$ group and larger $t$ period), the use of two-step system GMM mitigates endogeneity in the variables. Thus, our selected data perfectly meet the criteria of two-step system-GMM, whose results are given in Table IV.

Furthermore, the quality of the instruments developed in system-GMM has been tested by a Hansen J-test and a difference-in-Hansen test. In two-step system-GMM, we also assume that the initial conditions remain informative and appropriate in the presence of endogenous regressors. Overidentifying restrictions used in the model have been examined by the second-order serial correlation test of Arellano and Bond (1988), and the results are reported at the end of Table IV.

The impact of different components of competitive industrial growth (industrial export quality, industrial intensity, per capita manufacturing exports, and per capita manufacturing value added) on carbon emissions has also been captured, as given in Table V.

\section{Results and discussion}

In recent years, developing countries have exhibited interest in industrial development to foster economic growth, and the present study highlights the role of steady industrial growth on carbon emissions in developing countries of Latin America and the Caribbean. The Industrial Development Point Panel has been used in the study to measure industrial growth, and the empirical results, based on a flexible system of the generalized method of moment, show that industrial growth is significantly contributing to carbon emissions in the selected developing countries. Moreover, the robustness of the results is examined by introducing different control variables. The results show that industrial growth shows a consistently positive sign, which confirms the positive role of industrial growth on carbon emissions. More precisely, the results given in fourth column of Table IV show that one unit increase in economic growth can stimulate carbon emissions of about 0.23 units, if all other factors considered are constant. This result is in line with earlier research, such as that of Ewing et al. (2007), Sari et al. (2008), Ziramba (2009), Chandran et al. (2010), Sheinbaum et al. (2011), and Govindaraju and Tang (2013).

We also synthesize our results by regressing various components of the industrial performance index, including per capita manufacturing value added, per capita manufacturing exports, industrial intensity, and export quality on carbon emissions. To examine the role of manufacturing on carbon emissions, we control country heterogeneity due to differences in population. The results show that the pace of industrialization (to improve per capita manufacturing value added) is contributing positively to carbon emissions at the national level. Moreover, at the international level, to reflect competitiveness in manufacturing and the transition from simple to sophisticated technologies, per capita manufacturing exports of final produced goods is used to show the potential of an economy to produce goods competitively by adopting sophisticated technologies. The results reflect that a rise in technological development (through the use of modern technologies) reduces carbon emissions. 
Table IV. Regression results.

\begin{tabular}{|c|c|c|c|c|}
\hline \multicolumn{5}{|c|}{ Dependent variable: CEM } \\
\hline \multirow{2}{*}{$\frac{\text { Variables }}{\text { GDP }}$} & \multicolumn{4}{|c|}{ Method: two-step GMM (robust) } \\
\hline & $\begin{array}{c}0.754^{\mathrm{a}} \\
(0.281)\end{array}$ & $\begin{array}{l}0.597^{\mathrm{a}} \\
(0.244)\end{array}$ & $\begin{array}{c}0.358^{a} \\
(0.179)\end{array}$ & $\begin{array}{c}0.231^{\mathrm{a}} \\
(0.116)\end{array}$ \\
\hline $\mathrm{GDP}^{2}$ & $\begin{array}{l}-0.435^{b} \\
(0.238)\end{array}$ & $\begin{array}{c}-0.427^{b} \\
(0.222)\end{array}$ & $\begin{array}{l}-0.325^{b} \\
(0.102)\end{array}$ & $\begin{array}{l}-0.104^{b} \\
(0.048)\end{array}$ \\
\hline CIG & $\begin{array}{l}0.893^{\mathrm{a}} \\
(0.281)\end{array}$ & $\begin{array}{c}0.625^{\mathrm{a}} \\
(0.298)\end{array}$ & $\begin{array}{l}0.553^{\mathrm{a}} \\
(0.124)\end{array}$ & $\begin{array}{l}0.308^{\mathrm{a}} \\
(0.109)\end{array}$ \\
\hline FFE & - & $\begin{array}{l}1.474^{\mathrm{b}} \\
(0.491)\end{array}$ & $\begin{array}{c}1.198^{b} \\
(0.251)\end{array}$ & $\begin{array}{c}0.963^{b} \\
(0.308)\end{array}$ \\
\hline REC & - & - & $\begin{array}{l}-0.167^{\mathrm{a}} \\
(0.083)\end{array}$ & $\begin{array}{l}-0.151^{\mathrm{a}} \\
(0.079)\end{array}$ \\
\hline URB & - & - & - & $\begin{array}{l}1.293^{\mathrm{a}} \\
(0.487)\end{array}$ \\
\hline $\mathrm{CEM}_{(-1)}$ & $\begin{array}{c}1.831^{b} \\
(0.281)\end{array}$ & $\begin{array}{l}1.642^{b} \\
(0.462)\end{array}$ & $\begin{array}{c}1.397^{\mathrm{b}} \\
(0.365)\end{array}$ & $\begin{array}{c}1.099^{b} \\
(0.391)\end{array}$ \\
\hline Cons & $\begin{array}{l}2.741^{\mathrm{b}} \\
(0.914)\end{array}$ & $\begin{array}{l}1.866^{\mathrm{b}} \\
(0.398)\end{array}$ & $\begin{array}{l}2.749^{b} \\
(0.076)\end{array}$ & $\begin{array}{l}3.395^{\mathrm{b}} \\
(0.092)\end{array}$ \\
\hline Observations & 389 & 389 & 389 & 389 \\
\hline No. of Groups & 16 & 16 & 16 & 16 \\
\hline No. of Instruments & 14 & 14 & 12 & 11 \\
\hline $\begin{array}{l}\text { Wald } \mathrm{chi}^{2}(6) \\
\text { Prob. }>\mathrm{chi}^{2}\end{array}$ & $\begin{array}{l}932.36 \\
(0.000)\end{array}$ & $\begin{array}{c}1801.91 \\
(0.000)\end{array}$ & $\begin{array}{c}3068.57 \\
(0.000)\end{array}$ & $\begin{array}{c}4328.28 \\
(0.000)\end{array}$ \\
\hline Hansen J-test & $(0.201)$ & $(0.134)$ & $(0.198)$ & $(0.233)$ \\
\hline $\begin{array}{l}\text { Difference-in-Hansen } \\
\text { test, p-values }\end{array}$ & $(0.162)$ & $(0.113)$ & $(0.159)$ & $(0.207)$ \\
\hline Arellano-Bond AR (2) & 0.218 & 0.184 & 0.143 & 0.209 \\
\hline $\begin{array}{l}\text { a } 5 \% \text { level of significanc } \\
\text { CEM: carbon emissions, } \\
\text { GDP }^{2} \text { : square of econom } \\
\text { annual per capita fossil } \\
\text { REC: renewable energy } \\
\text { order autocorrelation te } \\
\text { standard errors are give }\end{array}$ & $\begin{array}{l}1 \% \text { leve } \\
\text { DP: gros } \\
\text { rowth; } C \\
\text { ls consul } \\
\text { nsumptic } \\
\text { in first d } \\
\text { a parenth }\end{array}$ & $\begin{array}{l}\text { f significa } \\
\text { lomestic pr } \\
\text { : competit } \\
\text { tion in me } \\
\text { URB: urb } \\
\text { ferences. I } \\
\text { es. }\end{array}$ & $\begin{array}{l}\text { e. } \\
\text { eindustria } \\
\text { c tons of } \\
\text { ization; A } \\
\text { teroscedas }\end{array}$ & $\begin{array}{l}\text { iic growth); } \\
\text { owth; FFE: } \\
\text { equivalent; } \\
\text { 2): second- } \\
\text { consistent }\end{array}$ \\
\hline
\end{tabular}

The impact of industrial intensity on carbon emissions is also examined in order to capture the variation involved in local production capabilities between the developing economies. The findings show a positive impact of industrial intensity growth on carbon emissions. More precisely, the results highlight that the absence of advanced technologies in these developing countries and the growth of medium-level 
Table V. Impact of competitive industrial performance on carbon emissions.

\begin{tabular}{|c|c|}
\hline \\
\hline \multicolumn{2}{|l|}{ Variables } \\
\hline Industrial export quality & $\begin{array}{r}0.523^{\mathrm{a}} \\
(0.306)\end{array}$ \\
\hline Industrial intensity & $\begin{array}{l}0.639^{b} \\
(0.346)\end{array}$ \\
\hline $\begin{array}{l}\text { Per capita manufacturing } \\
\text { exports }\end{array}$ & $\begin{array}{l}-0.032^{\mathrm{c}} \\
(0.014)\end{array}$ \\
\hline $\begin{array}{l}\text { Per capita manufacturing } \\
\text { value added }\end{array}$ & $\begin{array}{l}0.019^{\mathrm{b}} \\
(0.010)\end{array}$ \\
\hline Carbon emissions $(-1)$ & $\begin{array}{r}1.293^{\mathrm{b}} \\
(0.352)\end{array}$ \\
\hline Cons & $\begin{array}{l}1.081^{\mathrm{c}} \\
(0.747)\end{array}$ \\
\hline Observations & 400 \\
\hline No. of groups & 16 \\
\hline No. of instruments & 13 \\
\hline $\begin{array}{l}\mathrm{F}(4,400) \\
\text { Probability }>\mathrm{F}\end{array}$ & - \\
\hline $\begin{array}{l}\text { Wald chi2 (4) } \\
\text { Probability }>\text { chi }^{2}\end{array}$ & $\begin{array}{c}42.99 \\
(0.000)\end{array}$ \\
\hline Hansen J-test & $(0.192)$ \\
\hline Difference-in-Hansen test, p-values & $(0.117)$ \\
\hline Arellano-Bond AR (2) & 0.1438 \\
\hline
\end{tabular}

technology industries is significantly contributing to carbon emissions. The results demonstrate that industries producing quality export goods usually adopt advanced technologies and make a very low contribution to carbon emissions. Therefore, there is a need to develop a sophisticated industrial structure in these developing countries which manifests flexibility, maturity, and the ability to absorb technological advancements and to adopt environmentally friendly manufacturing methods.
Furthermore, to examine the impact of export quality on carbon emissions, the average of the share of medium- and high-technology products in manufactured exports and the share of manufacturing exports in total exports have been considered. The results show that export quality has a positive impact on carbon emissions. Thus, it can be concluded that industries which are not using advanced technology but are involved in export activities may have the ability to produce quality export goods (due to 
specialization toward certain goods) but may be unable to control carbon emissions. The results also highlight that industrial growth based on low- and medium-level technologies in developing economies are contributing to carbon emissions. Thus, the empirical results of the present study suggest the use of competitive and advanced technology-based industrial growth rather than obsolete-technology industrial growth in order to reduce carbon emissions.

In developing countries, carbon emissions are an outcome of many activities. Empirical results in Table IV reveal that a unit increases in the consumption of fossil fuels contributes to carbon emissions of about 0.96 units if all other factors are considered constant. Thus, consumption of fossil fuels for manufacturing goods raises carbon emissions in developing economies, which endorses the findings of Chang and Carballo (2011), Sheinbaum et al. (2011), and Zilio and Recalde (2011). Particularly in developing economies, low- and medium-level manufacturing industries have a higher per unit cost when massively consuming fossil fuels and generating abundant waste in the form of $\mathrm{CO}_{2}$. Technologically underdeveloped countries face multiple problems in the form of lower production, higher per unit costs, and massive greenhouse gas emissions (Apergis and Payne, 2010; Chang, 2010; Zilio and Recalde, 2011; Mudakkar et al., 2013; Zhang and Yang, 2013; Kais and Sami, 2016; Pablo-Remero and de Jesús, 2016; Hanif, 2017). Furthermore, in fostering economic growth, readily available fossil fuels are attractive inputs for developing countries to increase production of goods, but the harmful influence of such non-renewable energy sources on the environment is often overlooked (Halicioglu, 2011; Bekhet and Harun, 2012; Sadorsky, 2012; Hanif, 2017, 2018a). To the contrary, the empirical results in Table IV indicate that a unit increase in consumption of renewable energy sources reduces carbon emissions about 0.15 units, if all other factors considered constant. It can be concluded that continuous consumption of fossil fuels leads to a shortage of such non-renewable resources in the future, weakening the ability of developing countries to meet rising industrial growth.

The findings further highlight that an increase in economic growth contributes to carbon emissions, and these results are in line with the findings of Saboori et al. (2012), Hanif (2017), Salahuddin et al. (2015), Pablo-Romero and de Jesús (2016), and
Hanif and Gago-de-Santos (2017) . However, GDP ${ }^{2}$ has a statistically significant and inverse impact on carbon emissions. The positive relationship between economic growth and carbon emissions, along with the negative impact of $\mathrm{GDP}^{2}$ on carbon emissions, supports the Environmental Kuznets Curve hypothesis. The results reflect that, after reaching a certain turning point, a unit increase in $\mathrm{GDP}^{2}$ reduces carbon emissions about 0.14 units, if all other factors considered constant. Previously, Zeb et al. (2014), Saidi and Hammami (2015), Pablo-Romero and de Jesús (2016), van-Ruijven et al. (2016), Wang et al. (2016), Zhang and Gao (2016), and Hanif (2017, 2018b) have also determined an inverted U-shaped relationship between carbon emissions and economic growth. Moreover, the coefficient of lagged term $\mathrm{CEM}_{(-1)}$ shows that, in the current period, carbon emissions in the economies of Latin America and the Caribbean are significantly associated and depend on economic factors similar to those responsible for carbon emissions in previous years..

These results also show that in developing economies within the study region, urbanization has a positive impact on carbon emissions, endorsing the findings of van-Ruijven et al. (2016). In recent years, the rapid growth of cities in Latin America has been enhancing the importance of urban areas to overall economic growth and the population's well-being. Although rapid urban development has had inarguably positive socio-economic effects, it has meanwhile increased demand for manufacturing, transportation, public utilities, and other services (Hanif, 2017; Hanif et al. 2019a). Thus, the usual urbanization pattern in developing countries is putting additional pressure on natural resources and feeding higher energy demand, along with environmental effects (Soytas and Sari, 2003; Wolde-Rufael, 2005; Narayan and Smyth, 2005; Li et al., 2008; Chang, 2010; Wang et al., 2011; Hanif et al. 2019b). It is worth mentioning that GDP ${ }^{2}$ and REC have a negative impact on carbon emissions, with important implications to the findings of the present study.

Industrial growth for the sake of greater economic growth cannot be discarded; thus, the rise in demand for energy will be inevitable in developing economies. Moreover, improvements in economic growth are necessary to increase the standards of living of individuals, to cope with poverty, and to 
deal with other socio-economic challenges common in developing countries (Saidi and Hammami, 2015; Pablo-Romero and de Jesús, 2016; van-Ruijven et al., 2016; Wang et al., 2016; Hanif, 2017). To overcome growing carbon emissions in developing economies stemming from industrial growth and higher consumption of non-renewables, it is necessary to adopt competitive and advanced technologies and transition to the use of renewable energy sources.

\section{Conclusion}

The outcomes of this particular research project show that industrial growth and consumption of non-renewables (fossil fuels) are key factors contributing to carbon emissions in the developing economies of Latin America and the Caribbean, establishing an inverted U-shaped relationship between economic growth and carbon emissions in the region. The results further reveal that per capita manufacturing value added, industrial intensity, and medium-level manufacturing industries in these developing economies are contributing to carbon emissions. However, growth in per capita manufacturing exports of final goods, originating in competitive manufacturing industries, reduces carbon emissions. The study also highlights that industrial growth based on competitive manufacturing industries is very much needed in order to control carbon emissions and to improve economic growth, but that the transition from low to higher technologies may not be sufficient to decouple economic progress from carbon emissions.

Thus, there is a need to take action to restrain carbon emissions, even when they are not strictly linked to industrial growth. While developing economies have a significant reason to foster industrial growth, they are also generally reluctant to accept a proposal of environmentally friendly technologies, because such acceptance could raise the cost of production and impede economic growth. Also, carbon control through the adoption of new environmentally friendly technologies is asymmetrical across countries, due to differences in structural changes. For instance, if a country is already committed to controlling carbon emissions and is following low carbon emissions strategies, then any further action to control emissions could prove more expensive, and the country could prove unwilling to adopt such a course.

Therefore, each step for controlling carbon emissions in developing countries should be considered according to the existing situation of structural change. It can be concluded that in order to achieve a clean policy design, simultaneous convergence of industrial technology gaps and environmentally friendly technology gaps between developed and developing countries can better guarantee the meeting of joint targets to control carbon emissions. Finally, at the initial stage, the adoption of renewable energy resources will require a significant amount of investment. To solve issues of expense and investment, developing countries should introduce low-interest loan schemes and provide a subsidizing infrastructure together with the necessary equipment to produce carbon-free energy. The principal advantage of renewable energy in developing countries is that it will increase the supply of energy while also helping to foster environmentally friendly industrial growth.

\section{Supplementary material}

Auxiliary information to aid the interpretation of this article is available at: https://www.revistascca. unam.mx/atm/SupplementaryMaterial/52732-Anser-SupMat.pdf

\section{References}

Apergis N, Payne JE. 2010. The causal dynamics between coal consumption and growth: Evidence from emerging market economies. Applied Energy 87:1972-1977. https://doi.org/10.1016/j.apenergy.2009.11.035

Arellano M, Bond S. 1988. Dynamic Panel Data estimation using PPD: A guide for users. Institute for Fiscal Studies, London. Available at: https://pdfs.semanticscholar. org/3e82/dcc9dfc925821bb6d3350310059886dadaf4. pdf

Bekhet HA, Harun NHB. 2012. Energy essential in the industrial manufacturing in Malaysia. International Journal of Economics and Finance 4:129-137. https:// doi.org/10.5539/ijef.v4n1p129

Blundell R, Bond S. 1998. Initial conditions and moment restrictions in dynamic panel data models. Journal of Econometrics 87:115-143. https://doi.org/10.1016/ S0304-4076(98)00009-8 
Bond SR, Hoeffler A, Temple JR. 2001. GMM estimation of empirical growth models. CEPR Discussion Paper No. 3048. University of Bristol, Bristol, UK. Available at: https://ssrn.com/abstract $=290522$

Breusch TS, Pagan AR. 1979. A simple test for heteroscedasticity and random coefficient variation. Econometrica 47:1287-1294. https://doi.org/10.2307/1911963

Chandran VGR, Sharma S, Madhavan K. 2010. Electricity consumption-growth nexus: The case of Malaysia. Energy Policy 38:606-612. https://doi.org/10.1016/j. enpol.2009.10.013

Chang CC. 2010. A multivariate causality test of carbon dioxide emissions, energy consumption, and economic growth in China. Applied Energy 87:3533-3537. https://doi.org/10.1016/j.apenergy.2010.05.004

Chang CC, Carballo CFS. 2011. Energy conservation and sustainable economic growth: The case of Latin America and the Caribbean. Energy Policy 39:4215-4221. https://doi.org/10.1016/j.enpol.2011.04.035

ECLAC. 2015. On the basis of the World Resources Institute (WRI), Climate Analysis Indicators Tool (CAIT) 2015. Economic Commission for Latin America and the Caribbean. Washington, D.C. Available at: http:// cait2.wri.org.

Ewing BT, Sari R, Soytas U. 2007. Disaggregate energy consumption and industrial output in the United States. Energy Policy 35:1274-1281. https://doi.org/10.1016/j. enpol.2006.03.012

Fodha M, Zaghdoud O. 2010. Economic growth and pollutant emissions in Tunisia: An empirical analysis of the Environmental Kuznets Curve. Energy Policy 38:1150-1156. https://doi.org/10.1016/j.enpol.2009.11.002

Govindaraju VC, Tang CF. 2013. The dynamic links between $\mathrm{CO}_{2}$ emissions, economic growth, and coal consumption in China and India. Applied Energy 104:310-318. https://doi.org/10.1016/j.apenergy.2012.10.042

Halicioglu F. 2011. A dynamic econometric study of income, energy and exports in Turkey. Energy 36:33483354. https://doi.org/10.1016/j.energy.2011.03.031

Hanif I. 2017. Economics-energy-environment nexus in Latin America and the Caribbean. Energy 141:170-178. https://doi.org/10.1016/j.energy.2017.09.054

Hanif I, Gago-de-Santos P. 2017. The importance of population control and macroeconomic stability to reducing environmental degradation: An empirical test of the environmental Kuznets curve for developing countries. Environmental Development 23:1-9. https:// doi.org/10.1016/j.envdev.2016.12.003

Hanif I. 2018a. Impact of economic growth, nonrenewable and renewable energy consumption, and urbanization on carbon emissions in Sub-Saharan Africa. Environmental Science and Pollution Research 25:1505715067. https://doi.org/10.1007/s11356-018-1753-4

Hanif I. 2018b. Impact of fossil fuels energy consumption energy policies and urban sprawl on carbon emissions in East Asia and the Pacific: A panel investigation. Energy Strategy Reviews 21:16-24. https://doi. org/10.1016/j.esr.2018.04.006

Hanif I, Raza SMF, Gago-de-Santos P, Abbas Q. 2019a. Fossil fuels, foreign direct investment, and economic growth have triggered $\mathrm{CO}_{2}$ emissions in emerging Asian economies: Some empirical evidence. Energy 171:493-501. https://doi.org/10.1016/j.energy.2019.01.011

Hanif I, Aziz B, Chaudhry IS. 2019b. Carbon emissions across the spectrum of renewable and nonrenewable energy use in developing economies of Asia. Renewable Energy 143:586-595. https://doi.org/10.1016/j. renene.2019.05.032

Kais S, Sami H. 2016. An econometric study of the impact of economic growth and energy use on carbon emissions: Panel data evidence from fifty-eight countries. Renewable and Sustainable Energy Reviews 59:11011110. https://doi.org/10.1016/j.rser.2016.01.054

Kasman A, Duman YS. 2015. $\mathrm{CO}_{2}$ emissions, economic growth, energy consumption, trade, and urbanization in new EU member and candidate countries: A panel data analysis. Economic Modelling 44:97-103. https:// doi.org/10.1016/j.econmod.2014.10.022

Li J, Song H, Geng D. 2008. Causality relationship between coal consumption and GDP: Difference of major OECD and non-OECD countries. Applied Energy 85:421-429. https://doi.org/10.1016/j.apenergy.2007.10.007

Mudakkar SR, Zaman K, Khan MM, Ahmad M. 2013. Energy for economic growth, industrialization, environment, and natural resources: Living with just enough. Renewable and Sustainable Energy Reviews 25:580-595. https://doi.org/10.1016/j.rser.2013.05.024

Narayan PK, Smyth R. 2005. Electricity consumption, employment, and real income in Australia: Evidence from multivariate Granger causality tests. Energy Policy 33:1109-1116. https://doi.org/10.1016/j.enpol.2003.11.010 
Orubu CO, Omotor DG. 2011. Environmental quality and economic growth: Searching for Environmental Kuznets Curves for air and water pollutants in Africa. Energy Policy 39:4178-4188. https://doi.org/10.1016/j. enpol.2011.04.025

Pablo-Romero MDP, de Jesús J. 2016. Economic growth and energy consumption: The Energy-Environmental Kuznets Curve for Latin America and the Caribbean. Renewable and Sustainable Energy Reviews 60:13431350. https://doi.org/10.1016/j.rser.2016.03.029

Pao HT, Tsai CM. 2011. Modeling and forecasting $\mathrm{CO}_{2}$ emissions, energy consumption, and economic growth in Brazil. Energy 36:2450-2458. https://doi. org/10.1016/j.energy.2011.01.032

Peng SJ, Bao Q. 2006. China's economic growth and environmental pollution: An empirical test based on Generalized Impulse Response Function [J]. China Industrial Economy 5:15-23.

Rafiq S, Salim R, Nielsen I. 2016. Urbanization, openness, emissions, and energy intensity: A study of increasingly urbanized emerging economies. Energy Economics 56:20-28. https://doi.org/10.1016/j.eneco.2016.02.007

Robalino-López A, García-Ramos JE, Golpe AA, Mena-Nieto Á. 2014. System dynamics modeling and the Environmental Kuznets Curve in Ecuador (1980-2025). Energy Policy 67:923-931. https://doi. org/10.1016/j.enpol.2013.12.003

Saboori B, Sulaiman J, Mohd S. 2012. Economic growth and $\mathrm{CO}_{2}$ emissions in Malaysia: A cointegration analysis of the Environmental Kuznets Curve. Energy Policy 51:184-191. https://doi.org/10.1016/j. enpol.2012.08.065

Sadorsky P. 2012. Energy consumption, output, and trade in South America. Energy Economics 34:476-488. https://doi.org/10.1016/j.eneco.2011.12.008

Saidi K, Hammami S. 2015. The impact of $\mathrm{CO}_{2}$ emissions and economic growth on energy consumption in 58 countries. Energy Reports 1:62-70. https://doi. org/10.1016/j.egyr.2015.01.003

Salahuddin M, Gow J, Ozturk I. 2015. Is the long run relationship between economic growth, electricity consumption, carbon dioxide emissions, and financial development in Gulf Cooperation Council Countries robust? Renewable and Sustainable Energy Reviews 51:317-326. https://doi.org/10.1016/j.rser.2015.06.005

Sari R, Ewing BT, Soytas U. 2008. The relationship between disaggregate energy consumption and industrial production in the United States: An ARDL approach. Energy Economics 30:2302-2313. https:// doi.org/10.1016/j.eneco.2007.10.002

Sheinbaum C, Ruiz BJ, Ozawa L. 2011. Energy consumption and related $\mathrm{CO}_{2}$ emissions in five Latin American countries: Changes from 1990 to 2006 and perspectives. Energy 36:3629-3638. https://doi.org/10.1016/j. energy.2010.07.023

Soytas U, Sari R. 2003. Energy consumption and GDP: Causality relationship in G-7 countries and emerging markets. Energy Economics 25:33-37. https://doi. org/10.1016/S0140-9883(02)00009-9

Tamaziane A, Chousa JP, Vadlamannati KC. 2009. Does higher economic and financial development lead to environmental degradation? Evidence from the BRIC countries. Energy Policy 37:246-253. https://doi. org/10.1016/j.enpol.2008.08.025

Van-Ruijven BJ, Daenzer K, Fisher-Vanden K, Kober T, Paltsev S, Beach RH, Calderón SL, Calvin K, Labriet M, Kitous A, Lucena AFP, van Vuuren DP. 2016. Base-line projections for Latin America: Base-year assumptions, key drivers, and greenhouse emissions. Energy Economics 56:499-512. https://doi.org/10.1016/j. eneco.2015.02.003

Wang S, Zhou DQ, Zhou P, and Wang QW. 2011. $\mathrm{CO}_{2}$ emissions, energy consumption, and economic growth in China: A panel data analysis. Energy Policy 39:48704875. https://doi.org/10.1016/j.eneco.2015.02.003

Wang S, Li Q, Fang C, Zhou C. 2016. The relationship between economic growth, energy consumption, and $\mathrm{CO}_{2}$ emissions: Empirical evidence from China. Science of the Total Environment 542:360-371. https:// doi.org/10.1016/j.scitotenv.2015.10.027

Wolde-Rufael Y. 2005. Energy demand and economic growth: The African experience. Journal of Policy Modeling 27:891-903. https://doi.org/10.1016/j.jpolmod.2005.06.003

Zeb R, Salar L, Awan U, Zaman K, Shahbaz M. 2014. Causal links between renewable energy, environmental degradation, and economic growth in selected SAARC countries: Progress towards a green economy. Renewable Energy 71:123-132. https://doi.org/10.1016/j. renene.2014.05.012

Zhang L, Gao J. 2016. Exploring the effects of international tourism on China's economic growth, energy consumption, and environmental pollution: Evidence from a regional panel analysis. Renewable and Sustainable Energy Reviews 53:225-234. https://doi.org/10.1016/j. rser.2015.08.040 
Zhang W, Yang S. 2013. The influence of energy consumption of China on its real GDP from aggregated and disaggregated viewpoints. Energy Policy 57:76-81. https://doi.org/10.1016/j.enpol.2012.10.023

Zilio M, Recalde M. 2011. GDP and environment pressure: The role of energy in Latin America and the Caribbean.
Energy Policy 39:7941-7949. https://doi.org/10.1016/j. enpol.2011.09.049

Ziramba E. 2009. Disaggregate energy consumption and industrial production in South Africa. Energy Policy 37:2214-2220. https://doi.org/10.1016/j.enpol.2009.01.048 